\title{
FACTORS DETERMINING THE TRUST OF VEGETABLE FARMERS FOR INTERMEDIARIES IN EASTERN ETHIOPIA
}

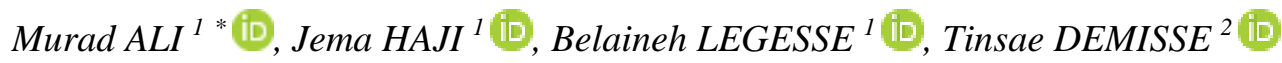

\author{
Address: \\ ${ }^{1}$ School of Agricultural Economics and Agribusiness, Haramaya University, P. O. Box: 138, Haramaya University, \\ Ethiopia \\ ${ }^{2}$ School of Agricultural Economics, Dilla University, P. O. Box: 419, Dilla University, Ethiopia \\ * Corresponding author: ahmedlimay2020@gmail.com
}

\begin{abstract}
Research background: There is higher level of mistrust between vegetable farmers and intermediaries in vegetable market transaction in Eastern Ethiopia. This mistrust adversely affected farmers' livelihood which largely depended on the agriculture sector. Hence understanding factors that affect trust of farmers for intermediaries is essential.

Purpose of the article: The purpose of this study is to analyse the factors determining vegetable farmers trust for intermediaries using cross sectional data collected from vegetable farmers in Eastern Ethiopia.

Methods: Multistage sampling was used to select 385 households for the study. The collected data were analysed using partial least square path modelling procedure.

Findings and value added: The empirical results indicated that relational investment, collaborative communication, and flexibility positively influenced trust. Moreover, collaborative communication and flexibility also positively influenced relational satisfaction. However, relational investment negatively affected opportunism.

Recommendation: Intermediaries should use effective communication to improve farmers trust and relational satisfaction. They should also engage in relational investment by giving assistance and advice as this could contribute to enhancement of trust and reduction of opportunism. Intermediaries need to also attract farmers by offering satisfactory price and demonstrating flexibility where it is necessary.
\end{abstract}

Key words: determinants of trust; Eastern Ethiopia; farmer-intermediary relationships; vegetables JEL Codes: D23; D43; D83; L13; Q12; Q13

\section{INTRODUCTION}

Vegetable farmers in eastern Ethiopia use the marketing channel that involve brokers to market their produce (Emana and Gebremedhin, 2007). There are up to three brokers operating between the primary producer and the trader. The brokers are paid a known commission for every quintal of vegetables transacted. The seldom contact between farmers and traders enabled brokers to set the price and hide their margin. Moreover, the lack of norm and regulation that control the activity of brokers also negatively affected farmers. Farmers in this market rely on intermediaries and traders they trade with for market information. This dependency made farmers vulnerable to opportunistic tendencies of intermediaries.

The transaction between vegetable farmers and intermediaries involve distrust and disputation regarding price, standards and schedule of payment. Farmers also face contract breach in the form of late payment, partial payment and non-payment in trade transaction with intermediaries (Jema, 2010). Hence the consequences of facing contract breach is serious as the livelihood of farmers largely depend on it. The consequence of lack of trust also create a condition where every transaction is scrutinized and checked which lead to an increase in transaction cost (Yeshitila et al., 2020). Effectiveness and efficiency which is important in supply chains is negatively affected. In addition, engaging in value adding activities with trading partners also become unthinkable and decision makers often spend their time analysing their trading partners' trustworthiness, reliability and credibility instead of concentrating on market transaction.

According to Sako (1998), trust is categorized as contractual, competence and goodwill trust. Contractual trust rest on the norm of keeping promise and honesty while competence trust is based on the expectation that the trading partner competently perform its role. The willingness of the trading partner to do more than expected is represented by goodwill trust. Kumar et al. (1995) defines trust to comprise the partner's honesty and benevolence. Hence, in this study, trust comprises the partner's attribute of honesty, promise keeping and benevolence (Sako, 1998; Kumar et al., 1995).

Different factors affect the trust between the farmers and their trading partners. Trust is positively influenced by pursuit of compatible goals, price satisfaction, relational satisfaction, specific investment, flexibility, collaborative relationship and good reputation between farmers and their trading partners (Batt, 2003a; Gyau and Spiller, 2007; Masuku and Kirsten, 2010; Fischer et al., 2007; 
Zinashbizu et al., 2020). Some of the factors may result in the undermining of trust between trading partners. These factors include coercive behaviour, cultural dissimilarity, opportunism and lack of cooperation (Masuku and Kirsten, 2010; Batt, 2003b; Gyau and Spiller, 2007). However, there is mixed result regarding the effect of duration of exchange relationship on trust (Masuku and Kirsten, 2010; Fritz and Fisher, 2007; Shulze and Spiller, 2006).

Most of the aforementioned studies on trust were conducted among trading partners in developed countries. However, few studies examined the determinants of trust of the farmer for the intermediary in the developing country context. Hence, in this study we identify factors that influence the trust of the vegetable farmer for an intermediary in Eastern Ethiopia.

\section{TRUST: THEORETICAL REVIEW}

Different definitions were given for trust construct. Sako (1998) recognizes three types of trust: contractual trust, competence trust, and goodwill trust. He argues that fulfilling a minimum set of obligations constitutes contractual trust, while honouring a broader set of obligations represent goodwill trust. Others contend trust comprises two essential elements; honesty and benevolence (Geyskens and Steenkamp, 1995; Kumar et al., 1995). Anderson and Narus (1990) define trust as the belief that business partners perform act that result in a positive outcome for the firm and not take unexpected actions that may result in negative outcomes.

Trust can be a significant part of social capital that contributes to economic development (Fukuyama, 1995; North, 1990; Ostrom, 2000; Dasgupta, 2000). Trust is related to institutions and affects the costs of transacting. If the confidence in an enforcement authority diminishes, trust in people will be less and agreements will not be established (Dasgupta, 2000). Trust by the buyer reduces the perception of risk and reduces transaction cost in an exchange relationship (Ganesan, 1994; Doney and Cannon, 1997).

In the relationship between the farmer and the intermediary, trust is expected to play a very important role in their transaction. Trust is expected to be influenced by opportunism, flexibility, price satisfaction, relational satisfaction, relational investment, power and communication relationship existing between the trading partners (Batt, 2003a; Batt, 2003b; Gyau and Spiller, 2007; Pusputwati et al., 2013; Massuku and Kirsten, 2010; Fischer et al., 2007).

\section{THE CONCEPTUAL FRAMEWORK OF THE STUDY}

Figure 1 illustrates the conceptual framework of this study showing the determinants of trust of the vegetable farmer for the preferred intermediary. Relational investment is based on three items and comprise getting advice on demanded vegetable variety and help during harvest from the preferred intermediary (Batt, 2003a). Collaborative communication is based on three items and includes frequent exchange of information and sharing of complete, correct and frank information (Boniface, 2011; Gyau and Spiller, 2007). Flexibility is based on four items and is represented by making arrangements fit with the current scenario, adjusting the contract condition and solving problems (Pusputwati et al., 2013).

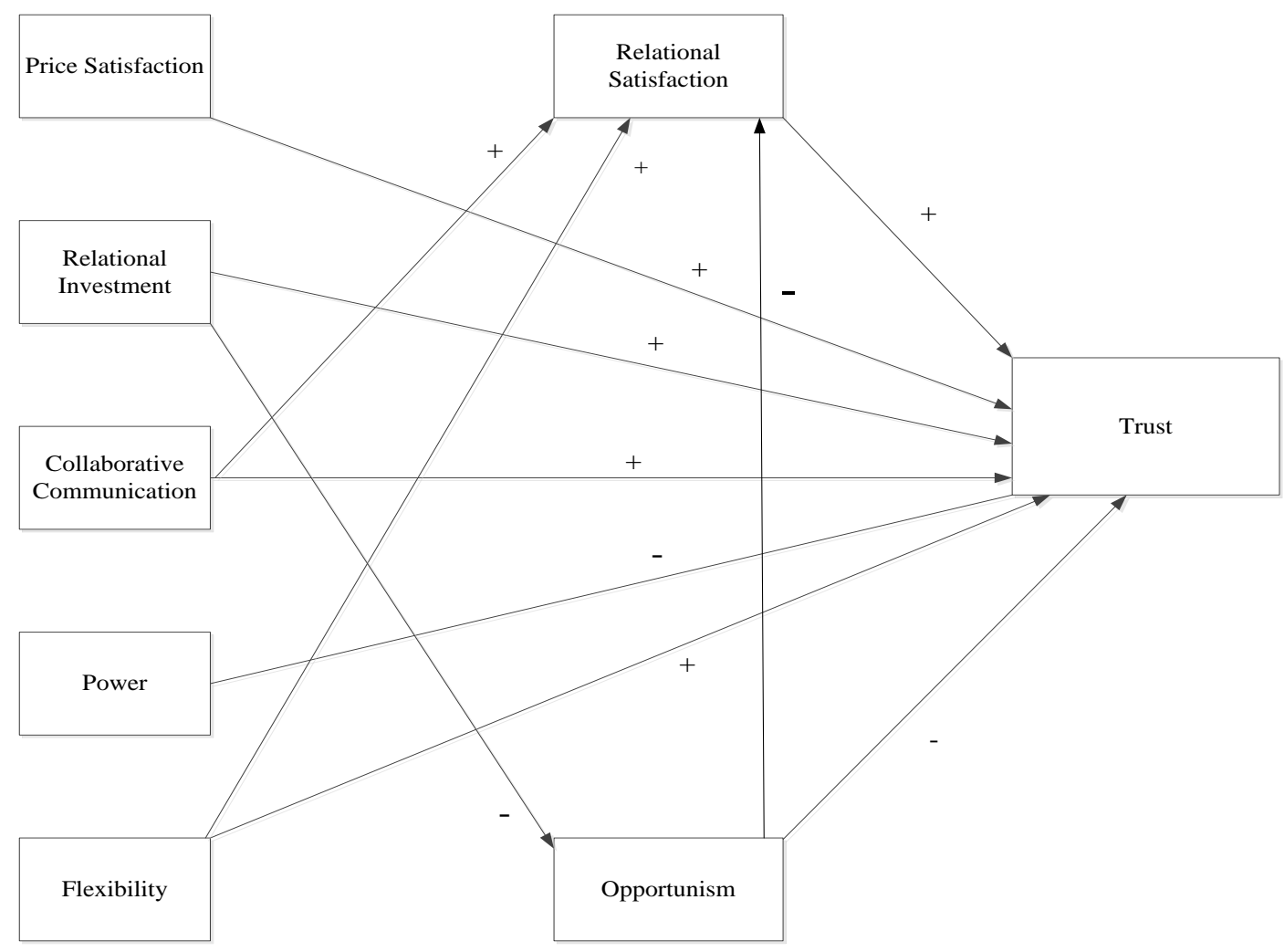

Figure 1. Conceptual framework of the study 
Table 1: Construct items for the trust and trust determining dimension

\begin{tabular}{|c|c|c|c|}
\hline \multirow{2}{*}{$\begin{array}{l}\text { Blocks } \\
\text { Relational } \\
\text { investment }\end{array}$} & \multicolumn{2}{|c|}{ Items } & \multirow{2}{*}{$\begin{array}{l}\text { Reference } \\
\text { Batt (2003a) }\end{array}$} \\
\hline & $\mathrm{X} 1$ & $\begin{array}{l}\text { My preferred market intermediary informs } \\
\text { me of the vegetable market condition } \\
\text { during wet and dry season }\end{array}$ & \\
\hline & $\mathrm{X} 2$ & $\begin{array}{l}\text { My preferred market intermediary helps } \\
\text { me during harvest in produce collection } \\
\text { without pay }\end{array}$ & Batt (2003a) \\
\hline & $\mathrm{X} 3$ & $\begin{array}{l}\text { My preferred market intermediary often } \\
\text { advises me of potential market demand }\end{array}$ & Batt (2003a) \\
\hline \multirow[t]{4}{*}{$\begin{array}{l}\text { Collaborative } \\
\text { Communication }\end{array}$} & $\mathrm{X} 4$ & $\begin{array}{l}\text { My preferred market intermediary provide } \\
\text { me with all the relevant market } \\
\text { information }\end{array}$ & Anderson and Narus (1990) \\
\hline & $\mathrm{X} 5$ & $\begin{array}{l}\text { We share common information frequently } \\
\text { with the preferred market intermediary }\end{array}$ & $\begin{array}{l}\text { Gyau and Spiller (2007); Boniface } \\
\text { (2011) }\end{array}$ \\
\hline & X6 & $\begin{array}{l}\text { Price changes are communicated to me in a } \\
\text { timely manner }\end{array}$ & Leat et al., (2010) \\
\hline & $\mathrm{X} 7$ & $\begin{array}{l}\text { The price information provided by my } \\
\text { preferred market intermediary is complete, } \\
\text { correct and frank }\end{array}$ & Han et al. (1993) \\
\hline \multirow[t]{4}{*}{ Flexibility } & $\mathrm{X} 8$ & $\begin{array}{l}\text { My preferred market intermediary is } \\
\text { flexible to make the arrangement fit with } \\
\text { the current scenario }\end{array}$ & Pusputawati et al., (2013) \\
\hline & $\mathrm{X} 9$ & $\begin{array}{l}\text { My preferred market intermediary can } \\
\text { adjust the contract condition to fit with my } \\
\text { present requirement }\end{array}$ & Pusputawati et al., (2013) \\
\hline & $\mathrm{X} 10$ & $\begin{array}{l}\text { When I have marketing related problem, } \\
\text { my preferred market intermediary will } \\
\text { make sure the problem does not } \\
\text { jeopardize our business relationship }\end{array}$ & Pusputawati et al., (2013) \\
\hline & $\mathrm{X} 11$ & $\begin{array}{l}\text { When I have problem with my preferred } \\
\text { market intermediary, we meet and solve } \\
\text { the problem together }\end{array}$ & Pusputawati et al., (2013) \\
\hline \multirow[t]{3}{*}{ Power } & $\mathrm{X} 12$ & $\begin{array}{l}\text { My preferred market intermediary has all } \\
\text { the power in setting price below my } \\
\text { expectation }\end{array}$ & $\begin{array}{l}\text { Gyau and Spiller(2007); Boniface } \\
\text { (2011) }\end{array}$ \\
\hline & $\mathrm{X} 13$ & $\begin{array}{l}\text { My preferred market intermediary controls } \\
\text { all the information regarding our } \\
\text { transaction (price and other market } \\
\text { information) }\end{array}$ & Batt (2003a) \\
\hline & $\mathrm{X} 14$ & $\begin{array}{l}\text { My preferred market intermediary uses } \\
\text { harsh language in transaction }\end{array}$ & Batt (2003b) \\
\hline \multirow[t]{4}{*}{ Price satisfaction } & $\mathrm{X} 15$ & $\begin{array}{l}\text { I agree with the vegetable produce price } \\
\text { and the grading system }\end{array}$ & Boniface (2011) \\
\hline & $\mathrm{X} 16$ & $\begin{array}{l}\text { I get a reasonable price quality-ratio (i.e. the } \\
\text { price obtained matches the value) }\end{array}$ & $\begin{array}{l}\text { Gyau and Spiller (2007); Boniface } \\
\text { (2011) }\end{array}$ \\
\hline & $\mathrm{X} 17$ & $\begin{array}{l}\text { The preferred market intermediary offer me } \\
\text { fair and reasonable price for my produce }\end{array}$ & Boniface (2011) \\
\hline & $\mathrm{X} 18$ & $\begin{array}{l}\text { The price that my preferred intermediary } \\
\text { offer me is higher than I expected }\end{array}$ & $\begin{array}{l}\text { Gyau and Spiller (2007);Boniface } \\
\text { (2011) }\end{array}$ \\
\hline \multirow[t]{3}{*}{ Opportunism } & $\mathrm{X} 19$ & $\begin{array}{l}\text { My preferred market intermediary does } \\
\text { not often act opportunistically by } \\
\text { increasing his margin }\end{array}$ & Batt (2003a) \\
\hline & $\mathrm{X} 20$ & $\begin{array}{l}\text { My preferred market intermediary is not } \\
\text { honest with me }\end{array}$ & Batt (2003a) \\
\hline & $\mathrm{X} 21$ & $\begin{array}{l}\text { My preferred market intermediary does not } \\
\text { offer me information which will benefit me }\end{array}$ & Williamson (1993) \\
\hline
\end{tabular}


Table 1 (continue): Construct items for the trust and trust determining dimension

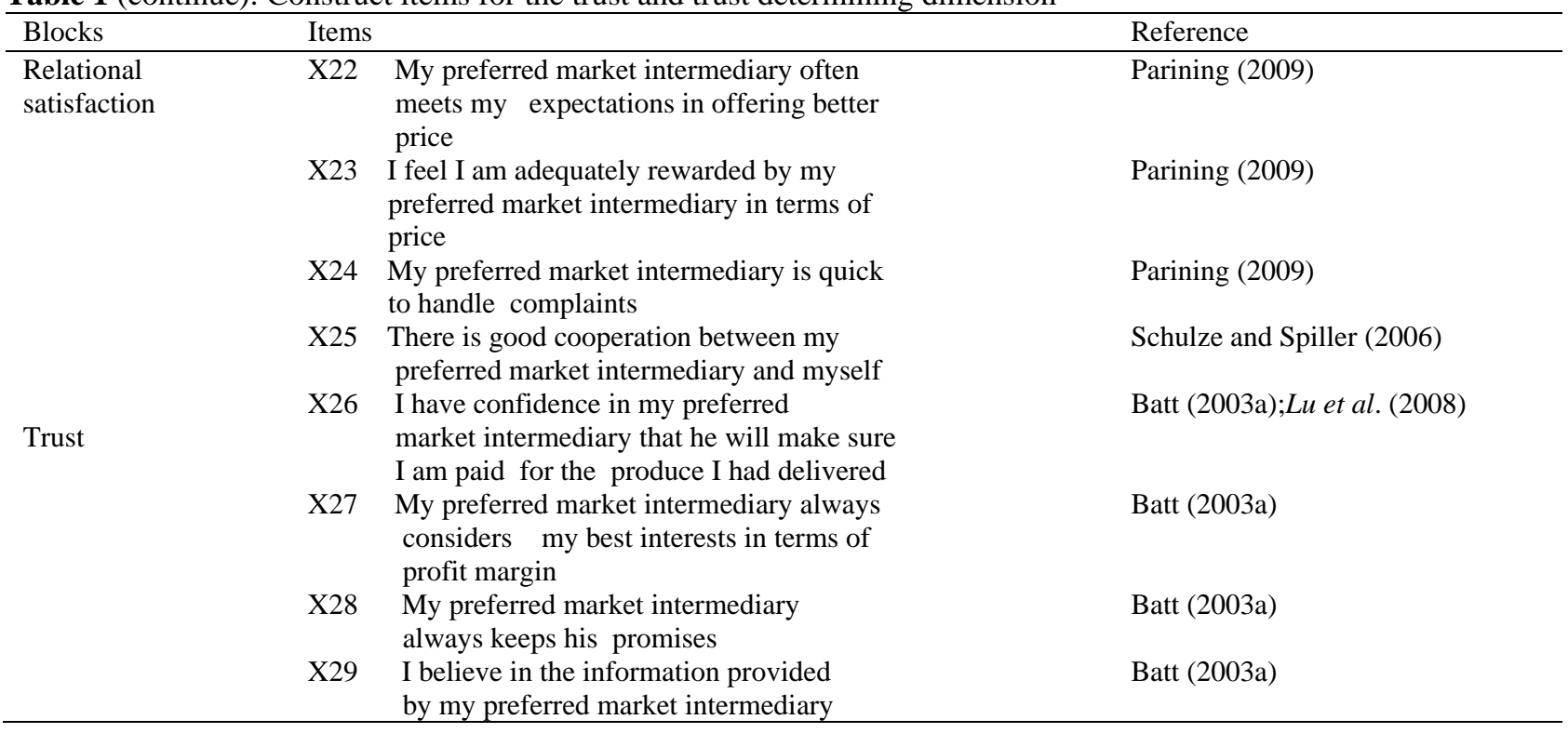

Power is based on three items and is represented by exercising power, controlling information and employing harsh language (Batt, 2003a; Gyau and Spiller, 2007). Price satisfaction is based on four items and is represented by agreement on price and grading, obtaining reasonable price-quality ratio and obtaining price higher than expected (Boniface, 2011; Gyau and Spiller, 2007). Opportunism is based on three items and is represented by acting opportunistically, dishonesty and failing to disclose information (Batt, 2003a; Williamson, 1993). Relational satisfaction is based on four item and is represented by handling complaints, treating fairly, meeting expectation, reducing conflict and showing good cooperation (Shulze and Spiller, 2006; Parining, 2009). Trust is based on four item and is represented by considering the interest of others, keeping promise and providing reliable information (Lu et al., 2008). Table 1 reports list of items used for data collection purpose.

\section{The study hypothesis}

Hypothesis 1: Trust is influenced positively by the extent to which the farmers most preferred intermediary is willing to make relationship specific investment.

Committing resources to the relationship is essential if the preferred intermediary wishes to improve its relationship to achieve future benefits. It is contended that any resource devoted beyond the amount required to facilitate the current exchange is regarded as an investment (Campbell and Wilson, 1996). According to Ganesan (1994), committing relationship specific investment indicates that the intermediary cares for the relationship, that the intermediary can be believed and that he can go as far as making more sacrifices. Hence, spending on relationship enhancing investment signals the trustworthiness of the intermediary.

Hypothesis 2. Trust is positively affected by engagement in collaborative communication with the vegetable farmer.

Communication is exchanging frequent, timely and meaningful information between transacting parties (Khalid and Ali, 2017). Effective communication (including its two component of adequate communication frequency and high information quality) is essential to good business relationship (Fischer et al., 2007). Some believe that effective communication occurs when detailed and meaningful information is shared between trading parties (Reynolds et al., 2009). It is also proposed that timely communication help solve conflicts that arise and lead to the development of sustainable business relationships. Studies indicate that both trust and satisfaction are positively influenced by communication in various trading relationships (Li et al., 2019).

Hypothesis 3: The extent of flexibility of the preferred intermediary to address the concern of the farmer positively influence the trust of the farmer for the intermediary.

This involve going beyond the terms and conditions specified in the contractual agreements as circumstances require (Heide and John, 1992). The positive response to request for change by the trading partner to contractual agreements enhances the trust between the trading partners. So making the necessary changes to the contractual agreements after considering the ongoing situation help the trading partners to build confidence and resolve problems that may happen in the future. Hence should an unexpected situation occur in the future, the parties would easily design new deal that considers the existing circumstances.

Hypothesis 4: The use of power by the farmer's preferred intermediary will negatively influence trust.

Trading partner that wield significant power in both an absolute and relative sense could easily influence his/her trading partners (Xhoxhi et al., 2019). This could have positive or negative consequence depending on how power is utilized by the powerful partner. If power is utilized to promote collective goals, high level of goal compatibility will exist otherwise not (Ganesan, 1994).

Hypothesis 5: Price satisfaction has positive influence on the farmers trust for the preferred intermediary. This refers to the affective satisfaction enjoyed by the seller from price related factors. Gyau and Spiller (2007) indicated that price satisfaction enhanced the trade 
relationship between trading parties in the international fresh produce business. Therefore, to enhance trust and develop sustainable relationship, the offer of reasonable and fair price by buyers to sellers is highly recommended (Susanty et al., 2017).

Hypothesis 6: Trust will be negatively impacted if the farmer's preferred intermediary engagement in opportunistic behaviour.

Opportunism refers to calculated efforts to confuse, mislead, or disguise the trading partner by providing incomplete and distorted information (Williamson, 1985). The deliberate strategy of forbearance with a view of future trade benefit and a demonstration of non-reneging behaviour is essential to sustaining a trusting relationship (Parkhe, 1993). Trust may prove still a risky investment even after trading with a partner for a long time. This is because the trustee could exploit the trustor at any time since the trustor is vulnerable (Lane, 2000). Moreover, detecting the risk of opportunism is also difficult as it is difficult to predict. Trading partners are tempted to be opportunistic to maximize gains over others (Gundlach $\boldsymbol{e t}$ al., 1995). However, this provokes retaliatory behaviour from the affected party instigating them to react with intensity (Yen and Hung, 2017). The deterioration of the trusting relationship leads to the severing and abandoning of the trade relationship.

Hypothesis 7: Relational satisfaction has positive influence on the trust of the farmer for the preferred intermediary.

Relational satisfaction is related with the trading partners' role with regard to solving problems, communication and negotiation (Gyau and Spiller, 2007). Moreover, it also concerns with fairness between the trading partners in trade relationship (DlaminiMazibuko, 2019). Moreover, relational satisfaction has an aspect of timeliness and punctuality. Hence relationships characterized by open communication, negotiation, equity and joint problem solving enhance the level of trust between partners.

Hypothesis 8: Relational investment by the intermediary negatively influence the perception of opportunism of the farmer towards the preferred intermediary.

If the intermediary wish to improve his/her relationship with the farmer, he will need to invest in various resources to strengthen the relationship (Ford $\boldsymbol{e t}$ al., 1996). Relational investment is expenditure in any resource committed in excess of the amount required to execute the current exchange transaction (Campbell and Wilson, 1996). Committing such resources help to smooth the trade relationship and reduce perception of opportunism.

Hypothesis 9: The collaborative communication between the farmer and the preferred intermediary positively influence relational satisfaction.

Relational problems occur due to communication difficulties and communication is regarded as a glue that hold together the market supply channel (Mohr and Nevin, 1990). Collaborative communication may improve the exchange partners' business relationship and enhance trust building by solving relationship problems (GlaveeGeo et al., 2020). Thus it is hypothesized that collaborative communication has a positive influence on relational satisfaction of the vegetable farmer towards his preferred intermediary.

Hypothesis 10: The flexibility of the transaction arrangement contributes to an increase in relational satisfaction of the farmer.

Flexibility is a dimension of relationship management practices that influence relationship outcomes (Heide and John, 1992). Relationship flexibility is conceptualized as the willingness to go beyond the terms and conditions stated in contractual agreement as the need arises (Johnson and Sohi, 2016). The need for flexibility in contract arises due to limited information availability, changing state of the environment and the managers bounded rationality in decision making (MacNeil, 1980). Hence, it is hypothesized that flexibility in market transaction positively influence relational satisfaction of vegetable farmers.

Hypothesis 11: Opportunistic behaviour of the intermediary influences negatively the relational satisfaction of the farmer.

Opportunism refers to the disclosure of distorted and/or incomplete information to mislead or confuse the trading partner (Williamson, 1985). The incentive to engage in opportunistic behaviour arises because one party decides to maximize its benefit ignoring the interest of the trading partner (Gundlach et al., 1995). If the trading partner detects opportunism, he/she will engage in retaliatory behaviour further deteriorating the relationship. Hence, the detection of opportunism causes relational satisfaction in trade transaction to decrease.

\section{DATA AND METHODS}

\section{Description of the study area}

East Hararghe zone is one of the 18 zones found in Oromia National Regional State with a population size of $3,039,680$ and with a population density of 151.87 persons $/ \mathrm{km}^{2}$ (CSA, 2007). The zone is characterized by mid latitude and lowland agro-climatic zones that range from 1600-2100 masl (meter above sea level) (CSA, 2007). The high inter-annual, spatial and inter-seasonal variations characterize the annual rainfall that range between 500-1200mm (CSA, 2007). The zone is bordered in the west with West Hararghe zone, Bale zone from the south, Somali Regional State from the east and south east and Dire Dawa council from the north. The three woredas(districts) randomly selected were Haramaya, Kombolcha and Kersa.

\section{Sample Size Determination}

The study employed the sample size determination formula given by Kothari (2004) to obtain a representative sample size (Eq.1).

$n=\frac{Z^{2} p q}{e^{2}}=\frac{(1.96)^{2}(0.5)(0.5)}{(0.05)^{2}}=385$

\section{Data collection and Sampling Procedure}

Structured questionnaire combined with guided interviews were used to collect information from vegetable farmers from the selected three woredas in East Hararghe zone 
namely Haramaya, Kombolcha and Kersa. Both primary and secondary data were collected from their respective sources. A set of prepared statements were used to collect information on the relationship between the farmer and his preferred intermediary on a 5-point scale from 1(strongly disagree) to 5(strongly agree). Information was collected on trust and trust determining factors.

Purposive and stratified sampling procedures were adopted to select the respondents. East Hararghe zone of Ethiopia was purposely selected as it is very well known in vegetable production. Then out of 9 potential vegetable producing woredas in the zone, three woredas were randomly chosen. The third stage involved the selection of sample vegetable producing kebeles(wards) from among the 34 potential vegetable producing kebeles of the randomly selected woredas while the fourth stage involved the random selection of 385 vegetable farmers from lists of names of households in the sampled Kebeles. The data was collected between June and August of 2018.

\section{Methods of data analysis}

Before conducting partial least square path modelling (PLSPM), the construct items for trust and trust determining factors were selected based on the literature and opinion of experts in vegetable marketing. For the theoretical verification of these constructs, exploratory factor analysis (EFA) was conducted (Hair et al., 2013). EFA identified eight factors with eigenvalues greater than one. Then determinants of trust were explored using partial least square path modelling (PLSPM). PLSPM was adopted for the following reasons: First, it does not require normality assumption (Henseler et al., 2016). Second, PLS accounts for the measurement errors and provides accurate estimates of the mediation effects (Chin, 1998). Third, it is possible to estimate path models using PLS for small sample sizes (Chin and Newsted, 1999). Fourth, it is possible to deal with complex causal models using PLSPM (Hulland, 1999). Fifth, the relationship among trust, relational satisfaction, relational investment, opportunism, collaborative communication, flexibility, power and price satisfaction needs further theoretical development.

PLS model is defined by two sets of linear equations: The inner model and the outer model. The inner model specifies the relationship between latent variables whereas the outer model specifies the relationships between a latent variable and its observed variables. The inner model can be written as Eq. 2.

$$
\varepsilon=\mathrm{B} \varepsilon+\mathrm{e}
$$

where $\varepsilon$ is the vector of latent variables, B represent the matrix of coefficients of the relationship, and e denotes the inner model residuals.

The outer models are of two types: reflective (Mode A) and formative (Mode B) measurement models. The choice of the outer model is underpinned by theoretical reasoning (Diamontopoulos and Winklhoter, 2001). The causal relationship from latent variable to the manifest variables represent reflective model (Eq.3).

$$
X_{x}=\varphi_{x} \varepsilon+e_{x}
$$

where $\varphi$ represent the loading (pattern) coefficients. The formative model of a measurement has a causal relationship from the manifest variables to the latent variable (Eq.4).

$\varepsilon=\pi_{x} X_{x}+e_{x}$

\section{RESULT AND DISCUSSION}

\section{Determinants of trust}

Measurement model assessment

The Cronbach alpha value of greater than 0.7 in Table 2 indicate the reliability of the blocks (Mackenzie and Podsakoff, 2011). Moreover, the blocks are considered homogenous if the DG.rho is larger than 0.7 (Sanchez, 2013). The Keiser rule states that the first eigenvalue should be greater than 1 and the second eigenvalue should be less than one based on Sanchez (2013). When the stated criteria were applied to the results, it was discovered that almost all of the blocks of items were found to be unidimensional (i.e. between 0.76 and 0.83 ) except power which was 0.63 . Similarly, the DG rho also lie between 0.80 to 0.88 for all the blocks. Moreover, the first eigenvalue is larger than 1 while the second eigenvalue is smaller than 1 further indicating the unidimensionality of the blocks.

Table 3 describes the results of the factor loading and communality estimates as the matrices for examining the correlation between indicators and their latent variables. The constructs are considered reliable if the factor loadings are greater than 0.7 for all items (Chin, 1998). The communality of a variable is the sum of the squared variance loadings of a variable and indicate how much latent constructs explain variance in measured variables (Sanchez, 2013). It is also indicated that the communality of above 0.49 and loadings of above 0.7 are considered acceptable (Sanchez, 2013). The obtained estimates from our result indicated that almost all values of the loading are greater than 0.7 except for an item power3R. The communality index for an item power $3 \mathrm{R}$ is 0.412 (i.e., $41.2 \%$ ) which imply that it is possible to reproduce $41.2 \%$ of the variance of an item from its respective block (power). For this reason, the item was kept in the model.

The matrix of cross loadings are the loadings of each item in each block (Sanchez, 2013). The criteria stated imply that the loadings of items in each block should be larger than its loading in other blocks. Hence, as Table 4 shows, all the items belonged to their respective blocks and hence are considered reliable. 
Table 2: Unidimensionality and validity measures of the model

\begin{tabular}{lllllll}
\hline Blocks & Mode & MVs & C.alpha & DG.rho & eig.1st & eig.2nd \\
\hline relinv & A & 3 & 0.784 & 0.875 & 2.101 & 0.588 \\
comcat & A & 4 & 0.783 & 0.860 & 2.425 & 0.594 \\
flex & A & 4 & 0.763 & 0.849 & 2.342 & 0.640 \\
power & A & 3 & 0.627 & 0.802 & 1.746 & 0.841 \\
prsat & A & 4 & 0.830 & 0.887 & 2.657 & 0.611 \\
opport & A & 3 & 0.764 & 0.865 & 2.042 & 0.593 \\
relsat & A & 3 & 0.741 & 0.853 & 1.976 & 0.530 \\
trust & A & 4 & 0.788 & 0.863 & 2.448 & 0.637 \\
\hline
\end{tabular}

Table 3: Factor loadings and communality estimates

\begin{tabular}{|c|c|c|c|c|c|c|}
\hline & Items & Blocks & Weight & Loading & Communality & Redundancy \\
\hline 1 & RI2 & relinv & 0.492 & 0.893 & 0.797 & 0 \\
\hline 2 & RI3 & relinv & 0.285 & 0.712 & 0.507 & 0 \\
\hline 3 & RI4 & relinv & 0.404 & 0.886 & 0.786 & 0 \\
\hline 4 & Comcat2 & comcat & 0.332 & 0.777 & 0.604 & 0 \\
\hline 5 & Comcat3 & comcat & 0.320 & 0.777 & 0.604 & 0 \\
\hline 6 & PT1 & comcat & 0.339 & 0.809 & 0.654 & 0 \\
\hline 7 & PT2 & comcat & 0.292 & 0.750 & 0.562 & 0 \\
\hline 8 & Flex1 & flex & 0.322 & 0.742 & 0.550 & 0 \\
\hline 9 & Flex2 & flex & 0.355 & 0.743 & 0.552 & 0 \\
\hline 10 & Flex & flex & 0.314 & 0.766 & 0.587 & 0 \\
\hline 11 & Joint & flex & 0.318 & 0.805 & 0.648 & 0 \\
\hline 12 & power2R & power & 0.370 & 0.731 & 0.534 & 0 \\
\hline 13 & power3R & power & 0.293 & 0.642 & 0.412 & 0 \\
\hline 14 & power6R & power & 0.657 & 0.825 & 0.680 & 0 \\
\hline 15 & PS1 & prsat & 0.348 & 0.837 & 0.700 & 0 \\
\hline 16 & PS2 & prsat & 0.310 & 0.858 & 0.736 & 0 \\
\hline 17 & PS3 & prsat & 0.309 & 0.841 & 0.708 & 0 \\
\hline 18 & PS4 & prsat & 0.256 & 0.714 & 0.511 & 0 \\
\hline 19 & noopport & opport & 0.493 & 0.900 & 0.810 & 0.126 \\
\hline 20 & trust2R & opport & 0.298 & 0.728 & 0.529 & 0.082 \\
\hline 21 & trust7R & opport & 0.407 & 0.834 & 0.695 & 0.108 \\
\hline 22 & $\mathrm{RS} 2$ & relsat & 0.409 & 0.812 & 0.659 & 0.392 \\
\hline 23 & RS4 & relsat & 0.412 & 0.806 & 0.649 & 0.386 \\
\hline 24 & RS5 & relsat & 0.411 & 0.817 & 0.668 & 0.397 \\
\hline 25 & Trust1 & trust & 0.305 & 0.758 & 0.575 & 0.373 \\
\hline 26 & Trust3 & trust & 0.340 & 0.841 & 0.708 & 0.460 \\
\hline 27 & Trust4 & trust & 0.321 & 0.759 & 0.576 & 0.375 \\
\hline 28 & Trust5 & trust & 0.312 & 0.767 & 0.589 & 0.383 \\
\hline
\end{tabular}

\section{Structural model assessment}

After examining and accepting the quality of the measurement model, the quality of the structural model was assessed by examining the redundancy index and $\mathrm{R}^{2}$ determination coefficients. The result of the total effect estimates, the path coefficients and the regression equations were also calculated to test the proposed hypotheses. Finally, goodness of fit (GOF) was checked to examine the reliability of the whole model. The predictive accuracy index $\left(\mathrm{R}^{2}\right)$ measures the variance of the dependent variable as influenced by the independent variables (Sanchez, 2013). The value of $\mathrm{R}^{2}$ of $0.25,0.50$ or 0.75 indicate weak, moderate and strong coefficient of determination (Hair et al., 2013).

Redundancy index shows the variance in the endogenous blocks as determined by the independent latent variables. The index shows the prediction ability. As the mean of the redundancy index gets higher, its prediction ability for the value of the indicators endogenous construct would also be higher (Sanchez, 2013). Moreover, the value of the average variance extracted (AVE) index should be greater than 0.5 for all blocks to be included in the structure and to yield a convergent validity which is acceptable (Fornell and Larcker, 1981).

In this study, the endogenous construct's (i.e. trust) $\mathrm{R}^{2}$ value is 0.65 (Table 5). This indicate that $65 \%$ of the variance of the trust construct is attributed to the remaining constructs. Relational investment explains $15.6 \%$ of the variance of the opportunism construct. Moreover, $59 \%$ of the variance of relational satisfaction was determined by the constructs flexibility, opportunism and collaborative communication. The mean redundancy value of $10.6 \%$ for opportunism imply that relational investment predicts $10.6 \%$ of the variability in opportunism indicator. Similarly, the mean redundancy value of $39.2 \%$ imply that flexibility, collaborative communication and opportunism predict $39.2 \%$ of the 
variability in relational satisfaction indicator. Moreover, $39.8 \%$ of the variability in trust indicator is predicted by the rest of the constructs. The last column is related to AVE indexes and for all the blocks the value range between 0.542 and 0.697 indicating convergent validity of the LVs.

The results of regression analyses ( $t$ value) and path coefficients in Table 6 showed that relational investment, collaborative communication, flexibility and price satisfaction influenced trust positively. This is supported by the findings of the study which indicated that specific asset investment by purchasers of agricultural products enhanced the trust of farmers in China (Chuang and Jia, 2016). Empirical studies also showed that communication improved trust between trading partners (Fischer, 2013; Pusputwati, 2013).

The study by Pusputwati (2013) in Indonesia also indicated that flexibility had positive impact on goodwill trust of Indofood (the largest food processing company in Indonesia) and GPF (General Potato Farmers) groups of farmers. The study in Ghana further showed that FFV (Fresh fruit and vegetables) exporting firms had more trust for importers who provided satisfactory price (Gyau and Spiller, 2007).

The result also indicated that relational investment negatively influenced opportunism. This finding is in agreement with the result of the study which indicated that information exchange, cooperation and relational satisfaction reduced the perception of opportunism in the buyer-supplier relationship in the cocoa industry in Ghana (Glavee-Geo, 2020). Moreover, both collaborative communication and flexibility also positively influenced relational satisfaction. This result confirms previous findings by Agarwal and Naryana (2020) which stated that relational communication positively influenced relational satisfaction in buyer supplier relationship. The study by Ivens (2005) further showed that customer satisfaction, trust and commitment were positively influenced by flexibility in the exchange between customers and their service providers.

Hence for all the aforementioned constructs, the hypothesis was supported. However, for the construct power, opportunism and relational satisfaction influencing trust, the hypothesis was not supported since they are not significant. Similarly, for the construct opportunism influencing relational satisfaction, the hypothesis was not supported as it is insignificant.

The relationship between exogenous and endogenous constructs are decomposed into direct and indirect effects (Table 7). The direct effect indicates that trust increases significantly with relational investment, collaborative communication, flexibility and price satisfaction. Similarly, collaborative communication and flexibility also directly increase with relational satisfaction. However, relational investment directly and negatively influence opportunism. The evaluation concerning the indirect effects show that all of the indirect effects are insignificant.

Table 4: Item cross-loading estimates

\begin{tabular}{|c|c|c|c|c|c|c|c|c|c|c|}
\hline & Name & Blocks & Relinv & Comcat & Flex & Power & Prsat & Opport & Relsat & Trust \\
\hline 1 & RI2 & Relinv & 0.893 & 0.611 & 0.604 & 0.364 & 0.660 & 0.434 & 0.532 & 0.676 \\
\hline 2 & RI3 & Relinv & 0.712 & 0.334 & 0.386 & 0.105 & 0.317 & 0.192 & 0.375 & 0.453 \\
\hline 3 & RI4 & Relinv & 0.886 & 0.564 & 0.531 & 0.266 & 0.609 & 0.313 & 0.510 & 0.600 \\
\hline 4 & Comcat2 & Comcat & 0.455 & 0.777 & 0.595 & 0.321 & 0.662 & 0.399 & 0.692 & 0.474 \\
\hline 5 & Comcat 3 & Comcat & 0.486 & 0.777 & 0.641 & 0.409 & 0.532 & 0.522 & 0.575 & 0.547 \\
\hline 6 & PT1 & Comcat & 0.502 & 0.809 & 0.574 & 0.452 & 0.649 & 0.530 & 0.560 & 0.631 \\
\hline 7 & PT2 & Comcat & 0.501 & 0.750 & 0.591 & 0.370 & 0.676 & 0.405 & 0.456 & 0.569 \\
\hline 8 & Flex1 & Flex & 0.530 & 0.629 & 0.742 & 0.334 & 0.627 & 0.417 & 0.536 & 0.521 \\
\hline 9 & Flex2 & Flex & 0.475 & 0.633 & 0.743 & 0.331 & 0.499 & 0.424 & 0.577 & 0.589 \\
\hline 10 & Flex & Flex & 0.437 & 0.492 & 0.766 & 0.256 & 0.511 & 0.284 & 0.519 & 0.513 \\
\hline 11 & Joint & Flex & 0.454 & 0.590 & 0.805 & 0.422 & 0.454 & 0.490 & 0.541 & 0.503 \\
\hline 12 & power $2 \mathrm{R}$ & Power & 0.188 & 0.302 & 0.269 & 0.731 & 0.225 & 0.355 & 0.278 & 0.244 \\
\hline 13 & power3R & Power & 0.232 & 0.256 & 0.181 & 0.642 & 0.212 & 0.305 & 0.265 & 0.193 \\
\hline 14 & power6R & Power & 0.273 & 0.476 & 0.438 & 0.825 & 0.383 & 0.701 & 0.348 & 0.434 \\
\hline 15 & PS1 & Prsat & 0.577 & 0.705 & 0.537 & 0.349 & 0.837 & 0.445 & 0.531 & 0.626 \\
\hline 16 & PS2 & Prsat & 0.575 & 0.687 & 0.635 & 0.402 & 0.858 & 0.442 & 0.595 & 0.557 \\
\hline 17 & PS3 & Prsat & 0.549 & 0.698 & 0.583 & 0.372 & 0.841 & 0.446 & 0.574 & 0.555 \\
\hline 18 & PS4 & Prsat & 0.437 & 0.522 & 0.471 & 0.141 & 0.714 & 0.174 & 0.499 & 0.460 \\
\hline 19 & noopport & Opport & 0.385 & 0.567 & 0.492 & 0.633 & 0.432 & 0.900 & 0.466 & 0.486 \\
\hline 20 & trust2R & Opport & 0.272 & 0.384 & 0.350 & 0.507 & 0.331 & 0.728 & 0.237 & 0.299 \\
\hline 21 & trust7R & Opport & 0.304 & 0.500 & 0.451 & 0.535 & 0.400 & 0.834 & 0.401 & 0.398 \\
\hline 22 & $\mathrm{RS} 2$ & Relsat & 0.516 & 0.595 & 0.586 & 0.357 & 0.541 & 0.389 & 0.812 & 0.447 \\
\hline 23 & RS4 & Relsat & 0.501 & 0.601 & 0.547 & 0.264 & 0.560 & 0.361 & 0.806 & 0.524 \\
\hline 24 & RS5 & Relsat & 0.380 & 0.597 & 0.603 & 0.374 & 0.542 & 0.380 & 0.817 & 0.447 \\
\hline 25 & Trust1 & Trust & 0.506 & 0.537 & 0.533 & 0.363 & 0.487 & 0.349 & 0.431 & 0.758 \\
\hline 26 & Trust3 & Trust & 0.501 & 0.613 & 0.627 & 0.348 & 0.553 & 0.435 & 0.501 & 0.841 \\
\hline 27 & Trust4 & Trust & 0.516 & 0.531 & 0.525 & 0.395 & 0.496 & 0.434 & 0.483 & 0.759 \\
\hline 28 & Trust5 & Trust & 0.687 & 0.545 & 0.495 & 0.245 & 0.592 & 0.312 & 0.404 & 0.767 \\
\hline
\end{tabular}


Table 5: Communality, Redundancy and Average variance extracted

\begin{tabular}{llllll}
\hline Blocks & Type & R2 & $\begin{array}{l}\text { Block } \\
\text { Communality }\end{array}$ & $\begin{array}{l}\text { Mean } \\
\text { Redundancy }\end{array}$ & AVE \\
\hline Relinv & Exogenous & 0 & 0.697 & 0 & 0.697 \\
Comcat & Exogenous & 0 & 0.606 & 0 & 0.606 \\
Flex & Exogenous & 0 & 0.584 & 0 & 0.584 \\
Power & Exogenous & 0 & 0.542 & 0 & 0.542 \\
Prsat & Exogenous & 0 & 0.664 & 0 & 0.664 \\
Opport & Endogenous & 0.156 & 0.678 & 0.106 & 0.678 \\
Relsat & Endogenous & 0.595 & 0.659 & 0.392 & 0.659 \\
Trust & Endogenous & 0.650 & 0.612 & 0.398 & 0.612 \\
\hline
\end{tabular}

Table 6: Results of hypothesis testing

\begin{tabular}{lcrrl}
\hline Blocks & Path coefficient $(\beta)$ & $\mathrm{t}$ value & $\operatorname{Pr}(>|\mathrm{t}|)$ & Results \\
\hline Relinv -> Trust & 0.351 & 8.179 & 0.000 & supported \\
Comcat -> Trust & 0.216 & 3.312 & 0.001 & supported \\
Flex -> Trust & 0.237 & 4.501 & 0.000 & supported \\
Power-> Trust & 0.075 & 1.771 & 0.077 unsupported \\
Prsat -> Trust & 0.115 & 2.070 & 0.039 & supported \\
Opport -> Trust & 0.022 & 0.482 & 0.630 unsupported \\
Relsat -> Trust & -0.065 & -1.338 & 0.182 unsupported \\
Relinv -> opport & -0.395 & -8.404 & 0.000 supported \\
Comcat -> Relsat & 0.462 & 8.465 & 0.000 supported \\
Flex -> Relsat & 0.359 & 6.958 & 0.000 supported \\
Opport -> Relsat & -0.002 & -0.054 & 6785.7 & unsupported \\
\hline
\end{tabular}

Table 7: Total effect

\begin{tabular}{|c|c|c|c|c|}
\hline & Relationships & Direct & Indirect & Total \\
\hline 1 & relinv -> opport & 0.395 & 0.000 & 0.395 \\
\hline 2 & relinv $->$ relsat & 0.000 & -0.001 & -0.001 \\
\hline 3 & relinv $->$ trust & 0.351 & 0.009 & 0.360 \\
\hline 4 & comcat $->$ relsat & 0.462 & 0.000 & 0.462 \\
\hline 5 & comcat $->$ trust & 0.216 & -0.030 & 0.186 \\
\hline 6 & flex -> relsat & 0.359 & 0.000 & 0.359 \\
\hline 7 & flex -> trust & 0.237 & -0.023 & 0.213 \\
\hline 8 & power $->$ trust & 0.075 & 0.000 & 0.075 \\
\hline 9 & prsat $->$ trust & 0.115 & 0.000 & 0.115 \\
\hline 10 & opport -> relsat & -0.002 & 0.000 & -0.002 \\
\hline 11 & opport -> trust & 0.022 & 0.000 & 0.022 \\
\hline 12 & relsat $->$ trust & -0.065 & 0.000 & -0.065 \\
\hline
\end{tabular}

Table 8: PLS path coefficient

\begin{tabular}{lrrrrr}
\hline & Original & Mean.Boot & Std.Error & perc.025 & perc.975 \\
\hline relinv -> opport & 0.395 & 0.400 & 0.048 & 0.309 & 0.496 \\
relinv -> trust & 0.351 & 0.346 & 0.054 & 0.249 & 0.451 \\
comcat -> relsat & 0.462 & 0.467 & 0.070 & 0.326 & 0.612 \\
comcat -> trust & 0.216 & 0.213 & 0.082 & 0.048 & 0.367 \\
flex -> relsat & 0.359 & 0.356 & 0.066 & 0.216 & 0.473 \\
flex -> trust & 0.237 & 0.235 & 0.057 & 0.133 & 0.360 \\
power -> trust & 0.075 & 0.077 & 0.037 & 0.010 & 0.174 \\
prsat -> trust & 0.115 & 0.128 & 0.062 & 0.020 & 0.251 \\
opport -> relsat & -0.002 & -0.002 & 0.044 & -0.099 & 0.079 \\
opport -> trust & 0.022 & 0.019 & 0.042 & -0.056 & 0.109 \\
relsat -> trust & -0.065 & -0.066 & 0.057 & -0.187 & 0.037 \\
\hline
\end{tabular}

\section{Overall quality of the model}

The Gof index-pseudo goodness of fit- measures the quality of the measurement as well as the structural models. The index is a geometric mean of the average communality and corresponds to the average $\mathrm{R}^{2}$ value
(Sanchez, 2013). The GoF index value of the model was 0.542 implying the entire model's average prediction power is $54.2 \%$. 


\section{Bootstrap validation}

The fact that PLSPM is non parametric statistical procedure precludes the test of significance of parameter estimates based on normal distribution. Hence the precision of the estimates need to be checked using the standard errors obtained from bootstrap validation. The bootstrap procedure involved the drawing of 200 samples (with replacement) from the original data set of 385 . So, 200 estimates for each parameter in the model as well as the standard deviation (standard errors) was obtained. Hence, 200 samples of 385 cases were drawn randomly for the original sample. Finally, the mean of the 200 estimates as well as their standard deviations were calculated. The result indicated that we accept seven hypotheses out of eleven hypothesis formulated.

The t-values of the parameters were calculated by dividing the original estimates of the parameter by the bootstrap standard error. The significance of the PLS parameters can be tested with the standard errors obtained from the bootstrap procedure. If parameters are at least twice their standard errors, they are considered significant. For example, as Table 8 shows, the effect of collaborative communication on trust is significant at $\alpha=0.5$ as the original estimate $(0.216)$ is at least twice its standard error $(\mathrm{t}=0.216 / 0.082=2.634)$ whereas the effect of opportunism on trust is insignificant $(\mathrm{t}=0.022 / 0.042=0.524)$. These results can also be confirmed from their respective confidence intervals. The confidence interval for collaborative communication -> trust does not contain zero indicating the significance of the parameter. However, the confidence interval related to opportunism $>$ trust does contain zero and thus statistically insignificant.

\section{CONCLUSION}

The findings of the study showed that collaborative communication, engaging in relational investment, offering attractive price and demonstrating flexibility enhanced the trust of the farmer for the preferred intermediary. Similarly, collaborative communication and flexibility in trade transaction increased relational satisfaction of the farmer. Moreover, intermediary's engagement in relational investment reduced the perception of opportunism.

Hence, the analysis suggests that to improve the farmers trust and increase relational satisfaction, intermediaries should use effective communication strategies with farmers. They should also promote relational investment by giving advice and assistance since these contribute to trust and reduce opportunism. Intermediaries must also attract farmers by offering fair and reasonable price as this strengthens the trust of the farmer. Flexibility must also be exercised by adjusting the contract arrangement and solving problems that might arise. The development of trust between the farmer and the intermediary reduces transaction cost and lead to increased trade.

Similar to other studies, this study has some limitations. The limitation is related with the number of measures used to operationalize the construct and the cross sectional nature of the data which doesn't permit to study long term relationship. The data is also based on a one sided interview with producers which doesn't take into account the perspective of intermediaries.

\section{Acknowledgments:}

We would like to acknowledge the financial support given by the Ethiopian Ministry of Education for the Ph.D. study. We would also like to thank the anonymous reviewers for the comments provided.

\section{REFERENCES}

AGARWAL, U., \& NARAYANA, S. A. (2020). Impact of relational communication on buyer-supplier relationship satisfaction: Role of trust and commitment. Benchmarking: An International Journal. https://doi.org/10.1108/BIJ-05-2019-0220

ANDERSON, J. C., \& NARUS, J. A. (1990). A model of distributor firm and manufacturing firm working relationships. Journal of Marketing, 54(1), 42-58. https://doi.org/10.2307/1252172

BATT, P. J. (2003a). Building trust between growers and market agents. Supply Chain Management: An International Journal, 8(1), 65-78. https://doi.org/10.1108/13598540310463378

BATT, P. J. (2003b). Building trust in the Filipino seed potato industry. Journal of International Food \& Agribusiness Marketing, 13(4), 23-41. http://doi/abs/10.1300/j047v13n04_03

BONIFACE, B., GYAU, A., \& STRINGER, R. (2011). The role of long term relationship in Malaysias fresh Milk supply chain. In: A. G. a. R. Stringer, ed. Buyer and Seller Relationship in Malaysia's Dairy Industry. Adelaide: Adelaide University, 46-75.

CAMPBELL, A. J., \& WILSON, D. T. (1996). Managed networks: Creating strategic advantage. In Networks in marketing, ED. Dawn Iacobucci. Thousand Oaks, CA: Sage.

CHIN, W. W. (1998). The partial least squares approach to structural equation modeling. In G.A. Marcoulides (Ed.), Modern methods for business research (pp. 295336). Mahwah, NJ: Lawrence Erlabaum Associates.

CHIN, W. W., \& NEWSTED, P. R. (1999). Structural equation modeling with small samples using partial least squares. In R. H. Hoyle (Ed.), Statistical strategies for small sample research (pp. 307-342). Thousands Oaks, CA: Sage.

CHUANG, Z., \& JIA, X. (2016). Specific asset investment, interpersonal trust and relationship stability in the contractual channel of agricultural products. Journal of Beijing Technology and Business University, 2016-01.

CENTRAL STATISTICAL AGENCY OF ETHIOPIA. 2007. 2007 population and housing census of Ethiopia. Addis Ababa, Ethiopia.

DASGUPTA, P. (2000). Economic progress and the idea of social capital. In Dasgupta, $\mathrm{P}$ and Serageldin, I (Eds). Social capital: A multifaceted perspective. The World Bank, Washington, DC, 172-214.

DIAMANTOPOULOS, A., \& WINKLHOFER, H. M. (2001). Index construction with formative indicators: An alternative to scale development. Journal of 
Marketing Research, 38(2), 269-277. https://doi.org/10.1509/jmkr.38.2.269.18845

DONEY, P. M., \& CANNON, J. P. (1997). An examination of the nature of trust in buyer seller relationships. Journal of Marketing, 61(2), 35-51. https://doi.org/10.2307/1251829

DLAMINI-MAZIBUKO, B. P., FERRER, S., \& ORTMANN, G. (2019). Examining the farmer-buyer relationships in vegetable marketing channels in Eswatini. Agrekon, 58(3),1-18. https://doi.org/10.1080/03031853.2019.1596824

EMANA, B., \& GEBREMEDHIN, H. (2007). Constraints and opportunities of horticulture production and marketing in Eastern Ethiopia, Oslo: Drylands Coordnation Group.

FISCHER, C., GONZALEZ, M., HENCHION, M., \& LEAT, P. (2007). Trust and economic relationships in selected European agri-food chains. Acta Agriculturae Scandinavica, 4(1), 40-48. https://doi.org/10.1080/16507540701192543

FISCHER, C. (2013). Trust and communication in European agri-food chains. Supply Chain Management, 18(2), 208-218. https://doi.org/10.1108/13598541311318836

FORD, D., MCDOWELL, R., \& TOMKINS, C. (1996). Relationship strategy, investments and decision making in Iacobucci. D. (Ed.), Networks in marketing, Sage, New York, USA.

FORNELL, C., \& LARCKER, D. F. (1981). Evaluating structural equation models with unobservable variables and measurement error. Journal of Marketing Research, 18(1), 39-50. https://doi.org/10.2307/3151312

FRITZ, M., \& FISCHER, C. (2007). The role of trust in European food chains: Theory and empirical findings. International Food and Agribusiness Management Review, 10(2), 141-164. https://doi:0.22004/ag.econ.8185

FUKUYAMA, F. (1995). Trust: The social virtues and the creation of prosperity. London: Hamish Hamilton.

GANESAN, S. (1994). Determinants of long-term orientation in buyer-seller relationships. Journal of Marketing, 54(April), 1-19. https://doi.org/10.2307/1252265

GEYSKENS, I., \& STEENKAMP, J. B. E. M. (1995). An investigation into the joint effects of trust and interdependence on relationship commitment. In: Proceedings of the 24th Annual Conference of the European Marketing Academy, pp. 351-371.

GLAVEE-GEO, R., BURKI, U., \& BUVIK, A. (2020). Building trustworthy relationships with smallholder (small-scale) agro-commodity suppliers: Insights from the Ghana cocoa industry. Journal of Macromarketing, 40(1),110-127.

https://doi.org/10.1177/0276146719900370

GUNDLACH, G.T., ACHROL, R.S., \& MENTZER, J. T. (1995). The structure of commitment in exchange. Journal of Marketing, 59 (January), 78-92. https://doi.org/10.2307/1252016

GYAU, A., \& SPILLER, A. (2007). The role of organizational culture in modelling buyer-seller relationships in the fresh fruit and vegetable trade between Ghana and Europe. African Journal of Business Management, 1(8): 218-229. https://doi.org/10.5897/AJBM.9000633

HAIR, J. F., RINGLE, C. M., \& SARSTEDT, M. (2013). Partial least squares structural equation modelling: Rigorous applications, better results and higher acceptance. Long Range Planning, 46(1-2), 1-12. SSRN: https://ssrn.com/abstract=2233795

HAJI, J. (2010). The enforcement of traditional vegetable marketing contracts in the Eastern and Central parts of Ethiopia. Journal of African Economies, 19(5), 768792. https://doi.org/10.1093/jae/ejq012

HEIDE, J. B., \& JOHN, G. (1992). Do norms matter in marketing relationships? Journal of Marketing, 56(2), 32-44. https://doi.org/10.2307/1252040

HENSELER, J., HUBONA, G., \& RAY, P. A. (2016). Using PLS path modelling in new technology research: Updated guidelines. Industrial Management \& Data Systems, 116(1), 2-20. https://doi.org/10.1108/IMDS-09-2015-0382s

HULLAND, J. (1999). Use of partial least squares (PLS) in strategic management research: A review of four recent studies. Strategic Management Journal, 20(2), 195-204. $\quad$ https://doi.org/10.1002/(SICI)10970266(199902)20:2<195::AID-SMJ13>3.0.CO;2-7

IVENS, B. S. (2005). Flexibility in industrial service relationships: The construct, antecedents, and performance outcomes. Industrial Marketing Management, $34(6$ SPEC. ISS.), 566-576. https://doi.org/10.1016/j.indmarman.2004.10.007

JOHNSON, J. S., \& SOHI, R. S. (2016). Understanding and resolving major contractual breaches in buyerseller relationships: A grounded theory approach. Journal of the Academic Marketing Science, 44, 185-205. https://doi.org/10.1007/s11747015-0427-8

KHALID, S., \& ALI, T. (2017). An integrated perspective of social exchange theory and transaction cost approach on the antecedents of trust in international joint ventures. International Business Review. Elsevier Ltd, 26(3), 491-501. https://doi.org/10.1016/j.ibusrev.2016.10.008

KOTHARI, C.R. (2004). Research methodology: Methods and techniques. 2nd ed. New Delhi, India: New Age International.

KUMAR, N., SCHEER, L. K., \& STEENKAMP, J. B. E. M. (1995). The effects of perceived interdependence on dealer attitudes. Journal of Marketing Research, 32(3), 348-358. https://doi.org/10.2307/3151986

LANE, C. (2000). Introduction: Theories and issues in the study of trust. In: Lane, C. and Bachmann, R.(eds) Trust within and between organizations. Oxford University Press.

LEAT, P., HENCHION, M., ALBISU, L. M., \& FISCHER, C. (2010). Trust and relationships in selected European agri-food chains. In: FISCHER, C \& HARTMANN, M., ed. Agri-food chain relationships. Oxfordshire: CAB International, 91118.

LEMMA, Z., SRIPRUETKIAT, K., \& NITITHANPRAPAS, I. (2020). Factors affecting sustainability of business relationships in Ethiopia 
banana value chain. Journal of the Austrian Society of Agricultural Economics, 16(05), 83-95. ISSN: 18158129 E-ISSN: 18151027

LI, L., LI, G., FENG, X., LIU, Z., \& TSAI, F. S. (2019). Moderating effect of dynamic environment in the relationship between guanxi, trust, and repurchase intention of agricultural materials. International Journal of Environmental Research and Public Health, 16(19), 1-23. https://doi.org/10.3390/ijerph16193773

LU, H., TRIENEKENS, J. H., OMTA, S. W. F., \& FENG, S. (2008). Influence of guanxi, trust and farmerspecific factors on participation in emerging vegetable markets in China. Wagningen Journal of Life Sciences, 56(1-2), 21-38. https://doi.org/10.1016/S1573$\underline{5214(08) 80015-2}$

MACKENZIE, S. B., PODSAKOFF, P. M., \& PODSAKOFF, N. P. (2011). Construct measurement and validation procedures in MIS and behavioural research: Integrating new and existing techniques. MIS Quarterly, 35(2), https://doi.org/10.2307/23044045

MACNEIL, I. R. (1980). The new social contract. New Haven, CT: Yale University Press.

MOHR, J., \& NEVIN, J. (1990). Communication strategies in marketing channels: A theoretical perspective. Journal of Marketing, 54(4), 36-51. https://doi.org/10.2307/1251758

MASUKU, M. B., \& KIRSTEN, J. F. (2010). The role of trust in the performance of supply chains: A dyad analysis of smallholder farmers and processing firms in the sugar industry in Swaziland. Agrekon: Agricultural Economics Research, Policy and Practice in Southern Africa, 43(2), 147-161. http://www.tandfonline.com/loi/ragr20

NORTH, D. C. (1990). Institutions, institutional change and economic performance. Cambridge: Cambridge University Press.

OSTROM, E. (2000). Social capital: A fad or a fundamental concept? In: Social capital: A multifaceted perspective, edited by Dasgupta, P. and Serageldin, I., pp 172-214. Washington DC: World Bank.

PUSPITAWATI, E., GYAU, A., UMBERGER, W., \& STRINGER, R. (2013). Determinants of trust in the Indonesian potato industry. Washington: International Food Policy Research Institute.

REYNOLDS, N., FISCHER, C., \& HARTMANN, M. (2009). Determinants of sustainable business relationships in selected German agri-food chains. British Food Journal, 111(8), 776-793. https://doi.org/10.1108/00070700910980919

PARINING, N. (2009). Trust building behaviour within the Balinese fresh produce industry. SOCA: Jurnal Sosial Ekonomi Pertanian, 9 (2), 214 -222. https://ojs.unud.ac.id/index.php/soca/article/view/487 $\underline{15}$

PARKHE, A. (1993). Strategic alliance structuring: A game theoretic and transaction cost examination of inter-firm cooperation. Academy of Management Journal, 36(4), https://doi.org/10.2307/256759
SAKO, M. (1998). Does trust improve business performance? In: Lane C \& Backman R (eds), Trust within and between Organizations: Conceptual Issues and Empirical Application, pp 88-117. Oxford: Oxford University Press.

SANCHEZ, G. (2013). PLS Path Modelling with $R, R$ Package Notes. https://www.gastonsanchez.com/PLS_Path_Modeling _with_R.pdf

SHULZE, B., \& SPILLER. A. (2006). Determinants of trust between buyers and suppliers in agribusiness: empirical evidence from the German pork sector. Presented on seminar Trust and Risk in Business Networks: 117-125.

SUSANTY, A., BAKHTIAR, A., JIE, F., \& MUTHI, M. (2017). The empirical model of trust, loyalty, and business performance of the dairy milk supply chain: A comparative study. British Food Journal, 119(12), 2765-2787. $\quad$ https://doi.org/10.1108/BFJ-10-2016$\underline{0462}$

XHOXHI, O., STEFANLLARI, A., SKRELI, E., \& IMAMI, D. (2019). How intermediaries' power affects contract farming decisions: Evidence from the medicinal and aromatic plant sector in Albania. Journal of Agribusiness in Developing and Emerging Economies, $\quad 10(15), \quad 529-544$. https://doi.org/10.1108/JADEE-03-2019-0035

YEN, Y., \& HUNG, S. (2017). The influences of suppliers on buyer market competitiveness: An opportunism perspective. Journal of Business \& Industrial Marketing, 32(1), 18-29. https://doi.org/10.1108/JBIM-08-2015-0151

WILLIAMSON, O. E. (1985). The economic institutions of capitalism. The Free Press, New York.

YESHITILA, M., BUNYASIRI, I., \& SIRISUPLUXANA, P. (2020). The role of trust and transaction cost attributes to reduce side selling in sesame contract farming in Ethiopia. Journal of the Austrian Society of Agricultural Economics, 16(05), 97-109. ISSN: 18158129 E-ISSN: 18151027

WILLIAMSON, O. E. (1993). Opportunism and its critics. Managerial and Decision Economics, 14, 97107. https://doi.org/10.1002/mde.4090140203 